\title{
Environmental constraints structuring fish assemblages in riffles: evidences from a tropical stream
}

\author{
Fabrício Barreto Teresa ${ }^{1}$, Luzia Shirlei de Souza ${ }^{2}$, Dianne Michelle Alves da Silva², \\ Hugo de Oliveira Barbosa ${ }^{1}$, Jane Dilvana Lima ${ }^{3}$ and João Carlos Nabout ${ }^{1}$
}

\begin{abstract}
Riffles are unique habitats regarding to assemblage structure. However, understanding how these assemblages respond to environmental variations in small spatial extents, as within a stream, is a challenge. We assess whether the quantitative structure and the trophic composition of fish assemblages vary predictably among stream riffles. We predict that the variation of environmental conditions will explain species abundance and trophic composition, with the latter presenting higher predictive power, since species would be filtered according to their traits (e.g. diet). Moreover, we expect that the low among-riffle dispersal limitation within a stream and the strong habitat filtering would result in lower importance of spatial variables in the structure of riffle fish assemblages. We tested these predictions by studying 18 riffles of a stream in the Central Brazil. Environmental variables, but not spatial ones, were the most important in explaining the variation in assemblages structure. Environmental variables explained a greater portion of the trophic structure variation $\left(\mathrm{R}^{2}=0.62\right)$ than of abundance $\left(\mathrm{R}^{2}=0.37\right)$, indicating that the variation on the trophic traits at community level are more predictable. These results also indicate that these assemblages are subject to environmental control, highlighting the importance of riffle characteristics in driving ecological processes within streams.
\end{abstract}

Corredeiras são habitats singulares no que se refere à estrutura das suas assembleias. Entretanto, a compreensão sobre como essas assembleias respondem às variações ambientais em pequenas extensões espaciais, como dentro de um riacho, ainda é um desafio. Avaliamos se a estrutura quantitativa das assembleias de peixes, assim como a sua composição trófica variam previsivelmente entre corredeiras de riachos. Predizemos que a variação nas condições ambientais explicará a abundância das espécies, assim como a sua composição trófica, entretanto, com uma maior proporção da variação explicada para a segunda, já que as espécies seriam filtradas de acordo com seus atributos (e.g. dieta). Além disso, esperamos que a pequena limitação para a dispersão entre as corredeiras de um mesmo riacho, associada à forte filtragem ambiental, resultaria em uma menor importância de variáveis espaciais na estruturação das assembleias de corredeiras. Para testar essas predições, estudamos 18 corredeiras de um rio do Brasil Central. As variáveis ambientais, e não as espaciais, foram mais importantes para explicar a variação na estrutura das assembleias. As variáveis ambientais explicaram uma maior proporção da variação da composição trófica $\left(R^{2}=0,62\right)$, em comparação com a abundância $\left(R^{2}=0,37\right)$, indicando maior previsibilidade na variação dos atributos relacionados a dieta em nível de comunidade. Esses resultados também indicam que essas assembleias são sujeitas a forte controle ambiental, destacando a importância das características desses habitats nos processos ecológicos dentro dos riachos.

Keywords: Environmental filters, Mass effect, Mesohabitat, Metacommunity, Trophic composition.

\section{Introduction}

The relative importance of the factors structuring biological communities varies spatially and temporally (Cavender-Bares et al., 2009). Dispersal limitation processes prevail in biogeographical scales while niche based processes tend to prevail in a metacommunity scale (GonçalvesSouza et al., 2014). Despite this generalization, the relative importance of such processes may vary among taxa and ecosystems due to biological (Gonçalves-Souza et al., 2014) and environmental constraints to dispersal (Logue et al., 2011; Heino et al., 2015). This disparity has motivated ecologists to study the processes responsible for community organization, combining different biological groups, ecosystems and temporal and spatial scales (Nabout et al., 2009; Grönroos et al., 2013; Algarte et al., 2014; Heino et al., 2015).

\footnotetext{
${ }^{1}$ Universidade Estadual de Goiás, Câmpus de Ciências Exatas e Tecnológicas, Rodovia BR 153, 3105 - Fazenda Barreiro do Meio, 75132-903 Anápolis, GO, Brazil. (FBT) fabricioteresa@yahoo.com.br (corresponding author), (HOB) hugobioueg@gmail.com, (JCN) jcnabout@gmail.com ${ }^{2}$ Universidade Estadual de Goiás, Câmpus de Porangatu, 76550-000 Porangatu, GO, Brazil. (LSS) luzshi@gmail.com, (DMAS) dianne.michelle.silva@gmail.com

${ }^{3}$ Universidade Estadual de Goiás, Câmpus de Iporá, Av. Brasília, 32, 76200-000 Iporá, GO, Brazil. janedilvana@yahoo.com
} 
In smaller spatial extent, such as riffles within streams, some species are more prone to disperse among sites, occurring even in suboptimal conditions (i.e., mass effect) ( $\mathrm{Ng}$ et al., 2009; Heino et al., 2015). This strong mass effect could thus homogenize the local communities, resulting in spatially structured assemblages (Heino et al., 2015). However, if dispersal rates are not high enough to cause mass effects, an environmental signature in the metacommunity structure should emerge, for example, as a consequence of habitat filtering (Datry et al., 2016). Riffles within streams are good model system to test these predictions, since they are ubiquitous habitats in streams, their assemblages are connected by dispersal (Heino et al., 2015), and are easily recognized, with clear boundaries (Frissel et al., 1986).

Riffles are unique habitats regarding to assemblage structure (Taylor, 2000; Bührnheim \& Cox-Fernandes, 2003; Langeani et al., 2005; Teresa \& Casatti, 2012). These habitats are shallow, have a high water flow velocity and hard substrate (Frissel et al., 1986) and, for these reasons, they are environmentally restrictive for most species in lotic ecosystems. According to environmental filtering concept, local occurrence of species would be associated with the presence of adaptations, expressed as biological attributes that match the local environmental constraints (filters) (Poff, 1997). In riffles, fish exhibit a specific set of traits that enable dealing with the hydraulic and ecology challenges occur in such environments (Teresa \& Casatti, 2012). Riffle-dwelling fishes have hydrodynamic body and adaptations for fixation at the bottom or to live among rocks. Such adaptations minimizes energy expenditure and prevents the strong current from sweeping away individuals (Casatti \& Castro, 1998). Riffles have also been associated with the occurrence of species more specialized in their diet (Angermeier \& Karr, 1983; Teresa \& Casatti, 2012).

Understanding how the riffle assemblages respond to spatial variations within streams is still a challenge (Taylor, 2000). Despite their typical characteristics, among-riffle variation in environmental conditions may influence the structure of their fish assemblages. The theory predicts that co-occuring species will converge in their traits in response to local environmental constraints (Keddy, 1992), resulting in strong trait-environment relationship in the metacommunity level. Despite the scarcity of evidences relating to trait-environment relationship in the riffle-scale, we could expect, for example, a higher contribution of drift items (e.g. allochthonous invertebrates and plant material) in the fish diet in deeper and slower velocity riffles, as these conditions are suitable for water column drift feeders species (Teresa \& Casatti, 2013). In addition, the higher contribution of periphytivorous species in riffles with rock and boulder substrate could be expected, since benthic algae biomass is known to be positively correlated with coarsegrained substrate (Munn et al., 2010). These examples, illustrate that changes on water flow velocity and substrate composition in riffle-scale could influence community assembly. This hypothesis assumes environmental control as the main factor structuring the assemblages of the riffles. We tested this hypothesis by studying 18 riffle fish assemblages in a stream in the Brazilian savanna (Cerrado biome). We predict that the environment will explain a greater proportion of variation in trophic than taxonomic composition, because environmental filters sort species into communities according to their traits (e.g. diet-related traits). Moreover, we expect that the low among-riffle dispersal limitation within a stream and the strong habitat filtering, preventing homogenization of assemblages via mass effect, would result in lower importance of spatial variables in the structure of riffle fish assemblages.

\section{Material and Methods}

Study area. We studied 18 riffles along about $1,500 \mathrm{~m}$ of a third order stream (Montividiu River), Santa Teresa river drainage, in the Upper Tocantins river system (Goiás State, Brazil). The distance between each pair of riffles was recorded with a metric tape following the watercourse (598.8 $\mathrm{m}$ of average pairwise distance). The selected riffles differ mainly in relation to width, depth, substrate, and flow velocity. The stream is relatively well preserved, with streamside forest buffers usually wider than $30 \mathrm{~m}$.

Biological, environmental and spatial data. We sampled riffles sequentially in the upstream direction, without use of blocking nets. We sampled fish once using dip nets and a seine net, which were set immediately downstream from the riffles (Uieda \& Castro, 1999). Then, the substrate was disturbed upstream by moving rocks and pebbles towards the net, causing the displacement of fish, which tend to be driven by the water flow into the net (Uieda \& Castro, 1999). The sampling procedures carried out in each riffle were finalized when no individual was captured after three consecutive attempts.

Specimens captured were euthanized with an overdose of clove oil (Lucena et al., 2013), fixed in 10\% formaldehyde solution in the field, and transferred to $70 \%$ ethanol solution $72 \mathrm{~h}$ later (Uieda \& Castro, 1999). Voucher specimens are deposited at the Coleção Zoológica de Vertebrados da Universidade Estadual de Goiás (UEG 291 to 300). Fishes were collected with permission from the Instituto Brasileiro do Meio Ambiente e dos Recursos Naturais Renováveis (IBAMA license \# 34144-1).

When possible, the stomachs of 10 individuals of each species were analyzed. For less abundant species the largest possible number of individuals was analyzed, disregarding juveniles and individuals with empty stomachs. We removed the stomachs and analyzed under a stereoscopic microscope. Afterwards, we separated, identified and grouped food items into wider ecological and taxonomic categories: detritus; terrestrial invertebrates; aquatic invertebrates; plant material (seeds and leaf fragments) and filamentous algae. 
We calculated the Alimentary Index (AIi) for each food item, following Kawakami \& Vazzoler (1980) through the expression:

$$
A I_{i}=\frac{F_{i} \times V_{i}}{\sum_{n=1}^{n}\left(F_{i} \mathrm{x} V_{i}\right)} \times 100
$$

where: $\mathrm{AIi}=$ alimentary index $; \mathrm{n}=$ food item; $\mathrm{Fi}=$ frequency of occurrence $(\%)$ of each item; $\mathrm{Vi}=$ volume of each item in percentage.

We obtained the volume of each food item using a graduated plate, at a $1 \mathrm{~mm}$ height, with the values transformed into milliliters $\left(1 \mathrm{~mm}^{3}=0.001 \mathrm{ml}\right)($ Hellawell \& Abell, 1971). We calculated the frequency of occurrence of each item as the number of stomachs in which the item was found divided by the number of stomachs with contents. The trophic composition matrix was obtained by multiplying the abundance matrix by the alimentary index matrix for all species. The resulting matrix represents the importance of the food items in each assemblage, commonly known as CWM (Community Weighted Mean of Traits) (Lavorel et al., 2008).

We obtained the following environmental descriptors for each riffle: average depth (obtained in five equidistant points from one shore to another in at least three transversal transects), surface average, current velocity $\left(\mathrm{m} / \mathrm{s}^{2}\right.$; obtained with the floating object method, using a rubber ball), percentage of rocks, pebbles, gravel, boulder and sand (each type of substrate in each riffle was estimated through a visual inspection). Canopy shading was obtained from images taken with a camera positioned upward in the middle of the water channel at the height of one meter from the water surface, where the percent number of quadrants $(0.2 \times 0.2 \mathrm{~cm})$ of the image occupied by leaves, branches or trunks corresponded to vegetation cover.

Spatial filters were obtained from a Principal Coordinates of Neighbor Matrices (PCNM) (Borcard et al., 2004) applied to the matrix of watercourse distance among the riffles (Landeiro et al., 2011). The PCNM eigenvectors with positive eigenvalues are considered different and independent statements regarding how samples are spatially related to each other in different spatial scales (Borcard et al., 2004). The first filters correspond to a large-scale variation, since it comprises high eigenvalues and high spatial autocorrelation (Borcard et al., 2004). The other filters have low eigenvalues and low spatial autocorrelation, and therefore represent a thin-scale variation (Borcard et $a l ., 2004)$. Eight filters were generated for this study.

Data analysis. The response variables consisted on the abundance matrix (number of individuals per square meter) and the trophic composition matrix. We applied the Hellinger transformation on abundance and CWM matrix in order to relativize the weights of dominant species and traits (Legendre \& Gallagher, 2001). The environmental variables were standardized ( $z$ scores). These matrices were separately correlated with the environmental variables and the spatial filters (global models) using a redundancy analysis (RDA) (Legendre \& Legendre, 2012). Then we carried out the forward selection procedure to select the most important predictor variables in explaining the response variable when the global model was significant $(p<0.05)$. Two selection criteria are used in this procedure, the significance level and the adjusted coefficient of multiple determination calculated with all variables (global model) (Blanchet et al., 2008). Thus, a variable is retained in the reduced model if $\mathrm{p}<0.05$, and if the adjusted coefficient is not higher than the adjusted coefficient of the global model (Blanchet et al., 2008). We correlated the environmental and spatial variables selected using the forward selection procedure described above with the response variables using a Partial Redundancy Analysis (pRDA) when both global models were significant (Legendre \& Legendre, 2012), to assess the relative explanation of each set of predictor variables in regards to the response variables. The analyses were carried out in the R software (R Development Core Team, 2012).

\section{Results}

Riffles exhibited great variation regarding their environmental characteristics, especially flow, proportion of pebble, area and canopy shading (Table 1). On the other hand, depth and proportion of boulder had little variation among riffles (Table 1).

A total of 832 individuals were captured, consisting on 12 species of the orders Characiformes and Siluriformes. Siluriformes comprised the species Aspidoras sp., Cetopsorhamdia cf. iheringi Schubart \& Gomes, 1959, Imparfinis schubarti (Gomes, 1956), Phenacorhamdia sp., Vandellia cirrhosa Valenciennes, 1846, Hypostomus sp., Harttia punctata Rapp Py-Daniel \& Oliveira, 2001, and Rineloricaria lanceolata (Günther, 1868). Characiformes was represented by four species: Apareiodon machrisi Travassos, 1957, Characidium zebra Eigenmann, 1909, Creagrutus britskii Vari \& Harold, 2001, and Knodus cf. chapadae (Fowler, 1906). The most abundant species in the riffles were Characidium zebra, Knodus chapadae, and Hypostomus sp., representing together $71.15 \%$ of the total abundance. Apareiodon machrisi, Cetopsorhamdia cf. iheringi, Aspidoras sp., Harttia punctata, Vandellia cirrhosa, and Rineloricaria lanceolata, were the less abundant species, comprising $1.56 \%$ of the total abundance.

We analyzed 83 stomachs of 10 species that presented diet consisting mainly of aquatic insects or periphyton (Table 2). Two these species had low abundance and less than eight individuals with stomach content (Aspidoras sp. and Cetopsorhamdia cf. iheringi, with two and one individual analyzed, respectively). Other two species (Rineloricaria lanceolata and Vandellia cirrhosa) had empty stomachs (thus undetermined diet) and were not considered for the analysis of trophic composition of the assemblages. 
Table 1. Statistical summary of the environmental characteristics of the riffles.

\begin{tabular}{lcccc}
\hline $\begin{array}{l}\text { Environmental } \\
\text { variables }\end{array}$ & Mean & Minimum & Maximum & $\begin{array}{c}\text { Coefficient of } \\
\text { variation (\%) }\end{array}$ \\
\hline Width (m) & 3.60 & 1.15 & 5.9 & 139.28 \\
Length (m) & 6.05 & 3.00 & 11.5 & 299.75 \\
Area $\left(\mathrm{m}^{2}\right)$ & 21.08 & 4.83 & 53.34 & 57.43 \\
Depth $(\mathrm{cm})$ & 12.11 & 5.50 & 16.03 & 26.63 \\
Flow (m/sec) & 1.47 & 0.97 & 2.19 & 391.07 \\
Shading (\%) & 62.65 & 17.22 & 100.00 & 152.82 \\
Sand (\%) & 0.15 & 0.00 & 2.50 & 287.68 \\
Rock (\%) & 12.35 & 0.00 & 60.00 & 94.04 \\
Gravel (\%) & 0.01 & 0.00 & 0.14 & 87.04 \\
Pebble (\%) & 27.76 & 0.01 & 72.50 & 282.29 \\
Boulder (\%) & 26.16 & 0.23 & 78.33 & 20.23 \\
Root (\%) & 0.01 & 0.00 & 0.08 & 39.88 \\
\hline
\end{tabular}

Table 2. Alimentary Index values for the species analyzed. DT - Detritus; TI - Terrestrial Invertebrates; AI - Aquatic Invertebrates ; FA- Filamentous Algae ; PE - Periphyton; PM - Plant Material.

\begin{tabular}{lcccccc}
\hline Species & DT & TI & AI & FA & PE & PM \\
\hline Apareidon machrisi & 0 & 0 & 1.3 & 98.7 & 0 & 0 \\
Aspidoras sp. & 0 & 0 & 100 & 0 & 0 & 0 \\
Cetopsorhamdia cf. iheringi & 0 & 0 & 100 & 0 & 0 & 0 \\
Characidium zebra & 0 & 0.2 & 99.6 & 0 & 0 & 0.2 \\
Creagrutus britskii & 1.4 & 0 & 83.6 & 15.0 & 0 & 0 \\
Harttia punctata & 0 & 0 & 0 & 0 & 100 & 0 \\
Hypostomus sp. & 0 & 0 & 0 & 0 & 100 & 0 \\
Imparfinis schubarti & 0 & 10.5 & 87.8 & 1.7 & 0 & 0 \\
Knodus cf. chapadae & 0 & 47.2 & 23.7 & 0 & 0 & 29.2 \\
Phenacorhamdia sp. & 0 & 0 & 100 & 0 & 0 & 0 \\
\hline
\end{tabular}

Environmental variables significantly explained the variation in species abundance and in the trophic structure of the fish assemblages $(p<0.05$, Global models, abundance: $\mathrm{R}^{2}=0.48$; trophic composition: $\mathrm{R}^{2}=0.66$ ). The spatial filters exhibited no significant relationship with the response variables. The reduced model for the variation in species abundance comprised boulder, depth and flow velocity. The reduced model for trophic composition comprised gravel, rock, depth and flow velocity. The selected environmental variables explained a greater proportion of the variation of trophic composition $\left(\mathrm{R}^{2}=0.62\right)$ than of abundance $\left(\mathrm{R}^{2}=0.37\right)($ Table 3$)$.

Table 3. Results of the redundancy analysis for the species abundance and trophic composition. P-values lower than 0.05 are indicated in bold; PGenv - P-values of global environmental models; PGspa - P-values of global spatial models including eigenvectors associated with positive eigenvalues; env. sel. - environmental variables selected.

\begin{tabular}{lcccccc}
\hline $\begin{array}{l}\text { Response } \\
\text { matrix }\end{array}$ & $P$ Genv & $R^{2}$ adj & $P$ Gspa & $R^{2}$ adj & Env. sel. & $R^{2}$ adj \\
\hline $\begin{array}{l}\text { Abundance } \\
\begin{array}{l}\text { Trophic } \\
\text { composition }\end{array}\end{array}$ & $\mathbf{0 . 0 0 1}$ & 0.48 & 0.74 & -0.12 & $\begin{array}{c}\text { boulder + flow }+ \\
\text { depth } \\
\text { gravel + rocks }+\end{array}$ & 0.37 \\
\hline
\end{tabular}

Environmental variables in the reduced models were associated to the species and food items (Fig. 1). Species such as Harttia punctata and Hypostomus sp. were associated with riffles with higher flow velocity and boulder, respectively, while Phenacorhamdia sp. was associated with shallow environments (Fig. 1a). Aquatic invertebrates were more consumed in riffles with a higher proportion of gravel substrate, while the periphyton feeders occurred in greater abundance in riffles with higher flow velocity and rocky substrate (Fig. 1b). Terrestrial invertebrates and plant material were mainly consumed by fish in deeper riffles (Fig. 1b).

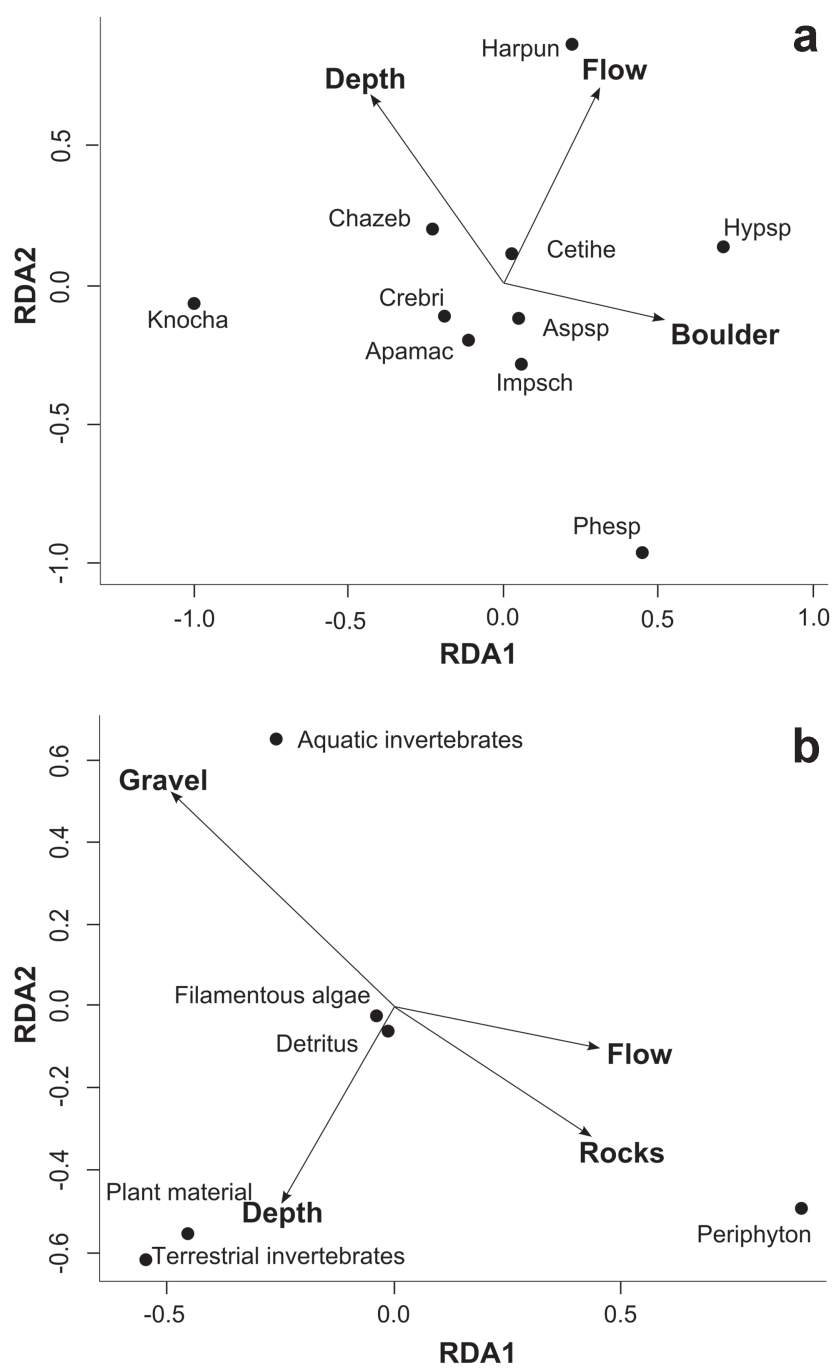

Fig. 1. Biplot of the Redundancy Analysis (RDA) of the reduced environmental model with species abundance (a) and trophic composition (b) as response variable. The first two axes of the RDA explained $92.4 \%$ of the speciesenvironment relationship and $98.1 \%$ of the trait-environment relationship. Species: Aspsp - Aspidoras sp.; Cetihe Cetopsorhamdia cf. iheringi; Impsch - Imparfinis schubarti; Phesp - Phenacorhamdia sp.; Hypsp - Hypostomus sp.; Harpun - Harttia punctata; Apamac - Apareiodon machrisi; Chazeb - Characidium zebra; Crebri - Creagrutus britskii; Knocha - Knodus cf. chapadae. 


\section{Discussion}

Variation in abundance and trophic structure of riffle fish assemblages was associated with the variation in the environmental conditions, but not with spatial distance. Substrate composition, depth and flow velocity are the more important filters driving among-riffle variation on the fish assemblage structure. These factors explained a very high variation in the fish abundance and trophic structure, which is consistent with the species sorting with efficient dispersal mechanism (sensu Winegardner et al., 2012). This model assumes strong environmental control on local species composition and that species have sufficient dispersal capacity to reach all local communities (Leibold et al., 2004), which is expected for habitats within a single stream, as in our case. These findings are in accord with our hypothesis, indicating the prevalence of niche-based processes in structuring riffle fish assemblages in the small spatial extents.

Lack of spatial structure in the riffle fish assemblages goes against the expectation that mass effects would have a prevalent role in structuring metacommunities in smaller spatial extents (Heino et al., 2015). The strength of the mass effect in smaller spatial extent would depend on the species dispersal abilities, and it will be larger for high-dispersal ones (Heino et al., 2015). Despite the incomplete knowledge about the dispersal abilities of stream fish, many riffledwelling species are known to be short distance swimmers and to exhibit sedentary habits (Casatti \& Castro, 1998). Therefore, among-riffle dispersal would be not high enough to homogenize the local assemblages. Furthermore, even for some high-dispersal species (e.g., water column swimmer Knodus cf. chapadae), environmental constraints in riffles (Angermeier \& Karr, 1983; Teresa \& Casatti, 2012) could to represent sufficiently limiting filters to neutralize the mass effect.

Our results corroborate the hypothesis that environmental variables have a higher predictive power on the trophic composition of assemblage than on its quantitative taxonomic structure. Indeed, we found that the environment explained a higher proportion of the variation in trophic structure than in species abundance. These results concur with studies carried out in large spatial scales (Hoeinghaus et al., 2007; Ibañez et al., 2009; Cunico et al., 2011) and show that assemblages in environmentally similar conditions must have high similarity in trophic composition, even if the taxonomic composition is different. In our case, different species, sharing the same diet, replace each other in environmentally similar riffles, reason by which the variation on the diet-related traits at community level were more predictable.

Two functional groups tend to prevail in stream riffles (Teresa \& Casatti, 2012), benthic grazers that feed on periphyton (Hypostomus sp., Harttia punctata and Apareiodon machrisi in our study) and aquatic insectivores that feed in the interstices of rocks (e.g. Phenacorhamdia sp.,
Imparfinis schubarti and Aspidoras sp. in our study). The differential availability of food resources among riffles must be one of the explanations for the distribution of species according to their trophic group. The high water flow velocity should contribute to the carrying of drift items such as detritus, plant material, terrestrial, and aquatic insects out of the riffles (Naman et al., 2016), while food items that are adhered in rigid substrates, such as periphyton tend to persist. On the other hand, the less restrictive influence of flow in deeper riffles should favor the occurrence of pelagic drift feeders (Casatti \& Castro, 1998), such as Knodus cf. chapadae in our study, explaining the association of depth with drift items as terrestrial invertebrates and plant material.

Our study shows that fish assemblages respond to variations in the physical structures of the riffles, notably, hydrological and geomorphological factors. These filters predict the quantitative structure and the trophic composition of the assemblages, highlighting the importance of riffle characteristics in driving ecological processes within streams. Spatial variation in fish assemblage structure is more predictable when the traits are taken into consideration, highlighting the benefits of consider the trait-based approach into a metacommunity perspective.

\section{Acknowledgements}

We thank the team of the Laboratório de Ciências Biológicas (UEG, Porangatu) for their assistance in sampling procedures; CAPES and FAPEG (AUXPE: 2036/2013) for the financial support in developing this study. LSS, DMS, and HOB thank UEG for financial support. JCN and FBT are supported by CNPq (processes 309700/2013-2 and 302158/2015-4, respectively).

\section{References}

Algarte, V. M., L. Rodrigues, V. L. Landeiro, T. Siqueira \& L. M. Bini. 2014. Variance partitioning of deconstructed periphyton communities: does the use of biological traits matter? Hydrobiologia, 722: 279-290.

Angermeier, P. L. \& J. R. Karr. 1983. Fish communities along environmental gradients in a system of tropical streams. Environmental Biology of Fishes, 9: 117-135.

Blanchet, F. G., P. Legendre \& D. Borcard. 2008. Modelling directional spatial processes in ecological data. Ecological Modelling, 215: 325-336.

Borcard, D., P. Legendre, C. Avois-Jacquet \& H. Tuomisto. 2004. Dissecting the spatial structure of ecological data at multiple scales. Ecology, 85: 1826-1832.

Bührnheim, C. M. \& C. Cox Fernandes. 2003. Structure of fish assemblages in Amazonian rain-forest streams: effects of habitats and locality. Copeia, 2003: 255-262.

Casatti, L. \& R. M. C. Castro. 1998. A fish community of the São Francisco River headwater riffles, southeastern Brazil. Ichthyological Exploration of Freshwaters, 9: 229-242. 
Cavender-Bares, J., K. H. Kozak, P. V. A. Fine \& S. W. Kembel. 2009. The merging of community ecology and phylogenetic biology. Ecology Letters, 12: 693-715.

Cunico, A. M., J. D. Allan \& A. A. Agostinho. 2011. Functional convergence of fish assemblages in urban streams of Brazil and the United States. Ecological Indicators, 11: 1354-1359.

Datry, T., A. S. Melo, N. Moya, J. Zubieta, E. Barra \& T. Oberdorff. 2016. Metacommunity patterns across three Neotropical catchments with varying environmental harshness. Freshwater Biology, 61: 277-292.

Frissell, C. A., W. J. Liss, C. E. Warren \& M. D. Hurley. 1986. A hierarchical framework for stream habitat classification: viewing streams in a watershed context. Environmental Management, 10: 199-214.

Gonçalves-Souza, T., G. Q. Romero \& K. Cottenie. 2014. Metacommunity versus biogeography: a case study of two groups of Neotropical vegetation-dwelling arthropods. PLoS ONE, 9: e115137.

Grönroos, M., J. Heino, T. Siqueira, V. L. Landeiro, J. Kotanen \& L. M. Bini. 2013. Metacommunity structuring in stream networks: roles of dispersal mode, distance type, and regional environmental context. Ecology and Evolution, 3: 4473-4487.

Heino, J., A. S. Melo, T. Siqueira, J. Soininen, S. Valanko \& L. M. Bini. 2015. Metacommunity organisation, spatial extent and dispersal in aquatic systems: patterns, processes and prospects. Freshwater Biology, 60: 845-869.

Hellawell, J. M. \& R. Abel. 1971. A rapid volumetric method for the analysis of the food of fishes. Journal of Fish Biology, 3: $29-37$

Hoeinghaus, D. J., K. O. Winemiller \& J. S. Birnbaum. 2007. Local and regional determinants of stream fish assemblage structure: inferences based on taxonomic vs. functional groups. Journal of Biogeography, 34: 324-338.

Ibañez, C., J. Belliard, R. M. Hughes, P. Irz, A. KamdemToham, N. Lamouroux, P. A. Tedesco \& T. Oberdorff. 2009. Convergence of temperate and tropical stream fish assemblages. Ecography, 32: 658-670.

Kawakami, E. \& G. Vazzoler. 1980. Método gráfico e estimativa do índice alimentar aplicado no estudo de alimentação de peixes. Boletim Instituto Oceanográfico, 29: 205-207.

Keddy, P. A. 1992. Assembly and response rules: two goals for predictive community ecology. Journal of Vegetation Science, 3: 157-164.

Landeiro, V. L., W. E. Magnusson, A. S. Melo, H. M. V. Espírito-Santo \& L. M. Bini. 2011. Spatial eigenfunction analyses in stream networks: do watercourse and overland distances produce different results? Freshwater Biology, 56: 1184-1192.

Langeani, F., L. Casatti, H. S. Gameiro, A. B. Carmo \& D. C. Rossa-Feres. 2005. Riffle and pool fish communities in a large stream of southeastern Brazil. Neotropical Ichthyology, 3: 305-311.

Lavorel, S., K. Grigulis, S. McIntyre, N. S. G. Williams, D. Garden, J. Dorrough, S. Berman, F. Quétier, A. Thébault \& A. Bonis. 2008. Assessing functional diversity in the field - Methodology matters! Functional Ecology, 22: 134-147.

Legendre, P. \& E. D. Gallagher. 2001. Ecologically meaningful transformations for ordination of species data. Oecologia, 129: 271-280.

Legendre, P. \& L. Legendre. 2012. Numerical Ecology. 3rd ed. Amsterdam, Elsevier, 1006p.
Leibold, M. A., M. Holyoak, N. Mouquet, P. Amarasekare, J. M. Chase, M. F. Hoopes, R. D. Holt, J. B. Shurin, R. Law, D. Tilman, M. Loreau \& A. Gonzalez. 2004. The metacommunity concept: a framework for multi-scale community ecology. Ecology Letters, 7: 601-613.

Logue, J. B., N. Mouquet, H. Peter, H. Hillebrand, P. Declerck, A. Flohrem, S. Gantner, N. Gülzow, P. Hörtnagl, S. Meier \& B. Pecceu. 2011. Empirical approaches to metacommunities: a review and comparison with theory. Trends in Ecology \& Evolution, 26: 482-491.

Lucena, C. A. S., B. B. Calegari, E. H. L. Pereira \& E. Dallegrave. 2013. O uso do óleo de cravo na eutanásia de peixes. Boletim da Sociedade Brasileira de Ictiologia, 105: 20-24.

Munn, M., J. Frey \& A. Tesoriero. 2010. The influence of nutrients and physical habitat in regulating algal biomass in agricultural streams. Environmental Management, 45: 603615.

Nabout, J. C., T. Siqueira, L. M. Bini \& I. S. Nogueira. 2009. No evidence for environmental and spatial processes in structuring phytoplankton communities. Acta Oecologica, 35: 720-726.

Naman, S. M., J. S. Rosenfeld \& J. S. Richardson. 2016. Causes and consequences of invertebrate drift in running waters: from individuals to populations and trophic fluxes. Canadian Journal of Fisheries and Aquatic Sciences, 73: 1292-1305.

Ng, I. S.Y., C. M. Carr \& K. Cottenie. 2009. Hierarchical zooplankton metacommunities: distinguishing between high and limiting dispersal mechanisms. Hydrobiologia, 619: 133-143.

Poff, N. L. 1997. Landscape filters and species traits: towards mechanistic understanding and prediction in stream ecology. Journal of the North American Benthological Society, 16: 391-409.

R Development Core Team. 2012. R: A language and environment for statistical computing. R Foundation for Statistical Computing, Vienna, Austria. Available from http://www.Rproject.org/.

Taylor, C. M. 2000. A large-scale comparative analysis of riffle and pool fish communities in an upland stream system. Environmental Biology of Fishes, 58: 89-95.

Teresa, F. B. \& L. Casatti. 2012. Influence of forest cover and mesohabitat types on functional and taxonomic diversity of fish communities in Neotropical lowland streams. Ecology of Freshwater Fish, 21: 433-442.

Teresa, F. B. \& L. Casatti. 2013. Development of habitat suitability criteria for Neotropical stream fishes and an assessment of their transferability to streams with different conservation status. Neotropical Ichthyology, 11: 395-402.

Uieda, V. S. \& R. M. C. Castro. 1999. Coleta e fixação de peixes de riachos. Pp. 1-22. In: Caramaschi, E. P., R. Mazzoni \& P. R. Peres Neto (Eds.). Ecologia de peixes de riachos. Rio de Janeiro, Programa de Pós-Graduação em Ecologia, Instituto de Biologia, Universidade Federal do Rio de Janeiro. (Oecologia Brasiliensis, v. 6).

Winegardner, A. K., B. K. Jones, I. S. Y. Ng, T. Siqueira \& K. Cottenie. 2012. The terminology of metacommunity ecology. Trends in Ecology \& Evolution, 27: 253-254.

Submitted December 22, 2015 Accepted August 02, 2016 by Lilian Casatti 